\title{
Distribution and characterization of wild bee nesting sites on San Clemente Island, California Channel Islands
}

\author{
C. Sheena Sidhu $1,2,{ }^{*}$ and Erin E. Wilson Rankin ${ }^{1}$ \\ ${ }^{1}$ Department of Entomology, University of California Riverside, Riverside, CA 92521 \\ ${ }^{2}$ Present address: University of California Cooperative Extension, \\ San Mateo \& San Francisco Counties, Half Moon Bay, CA 94019
}

\begin{abstract}
Wild bees provide the essential ecosystem service of pollination, which may be particularly important in island systems that host rare and endangered plants. Identifying and protecting nesting habitat of wild bees is critical for successfully conserving these pollinators and their pollination services, but characterization and delimitation of nesting habitat receives relatively little attention in the literature compared to description of floral interactions. Such data on wild bee nesting is necessary for creating effective conservation strategies that benefit the stability of ecosystem services, as well as promote the populations of both pollinators and plants. On San Clemente Island, we identified the locations of 50 bee nest sites. Bees from 12 sites were collected and identified as Diadasia bituberculata $(n=9)$, D. opuntiae $(n=2)$, and Anthidium collectum $(n=1)$. We characterized sites by vegetation cover and soil type: half $(54 \%)$ of the sites were found in maritime desert scrub-prickly pear phase vegetation, and most (82\%) were associated with loam-type soil. Here we provide the first descriptions of ground-nesting bee habitats on San Clemente Island and suggest that conservation of bee nesting habitat could be incorporated into existing avian and plant conservation management efforts in these shared habitats.
\end{abstract}

REsumen.-Las abejas silvestres cumplen una función esencial en la polinización del ecosistema, pudiendo ser particularmente importante en los sistemas insulares que albergan plantas exóticas y en peligro de extinción. Es fundamental identificar y proteger el hábitat de anidación de las abejas silvestres para conservarlas y para preservar sus funciones de polinización exitosamente, aunque la caracterización y la delimitación del hábitat de anidación reciben relativamente poca atención en la literatura en comparación con las interacciones florales. Esta información sobre la anidación de las abejas silvestres es necesaria para crear estrategias de conservación efectivas que beneficien la estabilidad de las funciones del ecosistema, así como para promover las poblaciones de los polinizadores y de las plantas. En la isla San Clemente, identificamos la ubicación de 50 sitios de anidación de abejas. Las abejas que se recolectaron en 12 sitios se identificaron como Diadasia bituberculata $(n=9)$, D. opuntiae $(n=2)$ y Anthidium collectum $(n=1)$. Caracterizamos los sitios según su cubierta vegetal y el tipo de suelo: la mitad de los sitios (54\%) se encontraron en matorrales desérticos marítimos (tuna en etapa vegetativa), y la mayoría $(82 \%)$ se asoció a suelos de tipo limosos. En este trabajo, proporcionamos las primeras descripciones de los hábitats de las abejas que anidan en el suelo de la isla San Clemente, y sugerimos que la conservación del hábitat de anidación de las abejas podría incorporarse a los actuales esfuerzos de conservación y de manejo de aves y de plantas en estos hábitats compartidos.

Wild bees provide the critical ecosystem service of pollination in natural and agricultural ecosystems. In efforts to protect rare, endemic plants in biodiversity hotspots (Myers et al. 2000), ecosystem-wide approaches to protecting pollinators of these plants are an integral part of effective conservation (Kearns et al. 1998). There has been great focus on identifying and supplementing floral resources for bee populations, typically in agricultural ecosystems (Haaland et al. 2011, Wratten et al. 2012, Blaauw and Isaacs 2014, M'Gonigle et al. 2016). However, nutritional resources alone cannot support a species. In addition to flowers, wild bees also require nesting habitat in order to persist in the environment (Potts et al. 2005, Michener 2007, Williams et al. 2010).

Of the 20,000 known bee species worldwide, most are solitary, ground-nesting bees (Cane 1991, Michener 2007). A typical groundnesting bee spends most of its 1-year lifecycle in the nest from egg through pupation until it emerges as an adult for a short period (typically several weeks) to mate, provision its nest,

*Corresponding author: csidhu@alumni.ucsd.edu 
and produce offspring (Michener 2007). Nesting sites are selected by adult female bees after mating. Preference for nesting site soil characteristics varies among bee species, with differences in moisture, composition, and temperature requirements (Cane 1991).

Despite its critical importance, far fewer studies have examined bee nesting habitat relative to studies examining floral resources (Dicks et al. 2013), and nesting requirements are rarely considered in plant conservation strategies or multispecies conservation programs. Overlooking nesting habitat in research and conservation may be due in part to the difficulty and extensive time required in locating nests (O'Connor et al. 2012), particularly in complex landscapes (Cane et al. 2007). Such difficulties may be further compounded by the lack of information about nesting habitat requirements for many species that could otherwise aid in nest searching.

It would therefore be beneficial to identify nesting habitat preferences for bee species and to develop an assessment framework that can be used by researchers and land managers. After key characteristics of nesting sites are identified, habitat management can be recommended in the same manner as floral resource management. Ideally, this information can be used with an understanding of plant-pollinator interactions to protect existing relationships that will contribute to protecting rare or threatened plants and their pollinators (Kearns et al. 1998).

Island systems are of particular interest for conservation due to the relatively high number of endemic species and unique subspecies they host (Kier et al. 2009). Here we show the first mapping of solitary bee nesting sites on San Clemente Island, California. Sites were identified by entomologists, botanists, and ornithologists who surveyed the island for different projects. Associated bees were collected when possible, and nest sites were mapped relative to landform, soil, and vegetation types. This collaborative effort among biologists supports the idea that bee habitat monitoring can be incorporated into existing management plans for other species and serves to benefit overall ecosystem management.

\section{MeTHODS}

San Clemente Island is approximately $34 \mathrm{~km}$ long, and $6 \mathrm{~km}$ at its widest point, with an area of $145 \mathrm{~km}^{2}$ (TDI 2013). It is approximately $125 \mathrm{~km}$ off the coast of San Diego, California, and $35 \mathrm{~km}$ from the nearest neighboring Channel Island, Santa Catalina Island. San Clemente Island hosts 23 known bee species (Rust et al. 1985) that are also found on mainland California; however, several subspecies are considered endemic to the island.

Bee nest sites were initially identified when the authors (entomologists) located nest aggregations while collaborating with botanists studying pollination of the island's rare plants. Nest sites were identified as the authors traversed the island in a semisystematic method en route to field sites located across the island but primarily on the western side of the southern half of the island. Sites were identified as aggregations of 25 to $200+$ nests at minimum densities of at least 3-5 nest entrances visible per square meter, although denser aggregations were also located. Sites (nest aggregations) were a minimum of $20 \mathrm{~m}$ apart. Nest entrances were circular, approximately $1 \mathrm{~cm}$ in diameter, and with or without turrets (Fig. 1). Additional nest sites were identified by ornithologists who opportunistically located sites while systematically scouting the island for endemic birds, except in restricted areas of the island, which were dominated by grasslands. The ornithologists were trained to identify nest sites based on search images, and they subsequently logged the geographic coordinates, took pictures of sites, and noted any bee activity. While neither the authors nor collaborators were specifically scouting only for bee nests, all nest locators were involved in projects that required systematic traversal of the island and careful observations and surveys of flora and fauna. Thus we believe that we have a representative sample of nest distributions on the island based on areas scouted, with more effort on the southern half of the island.

Nests sites were identified from January through June 2015. When active nests were found by the authors, bees were collected and brought to the University of California, Riverside (UCR), to be identified using identification keys and the reference collection at the UCR Entomology Research Museum (UCR ERM). All specimens have been deposited at the UCR ERM, Riverside, CA.

Nesting sites were mapped with ArcGIS 10.3 (ESRI, Redlands, CA). Landform, soil, and vegetation layers were used to describe 


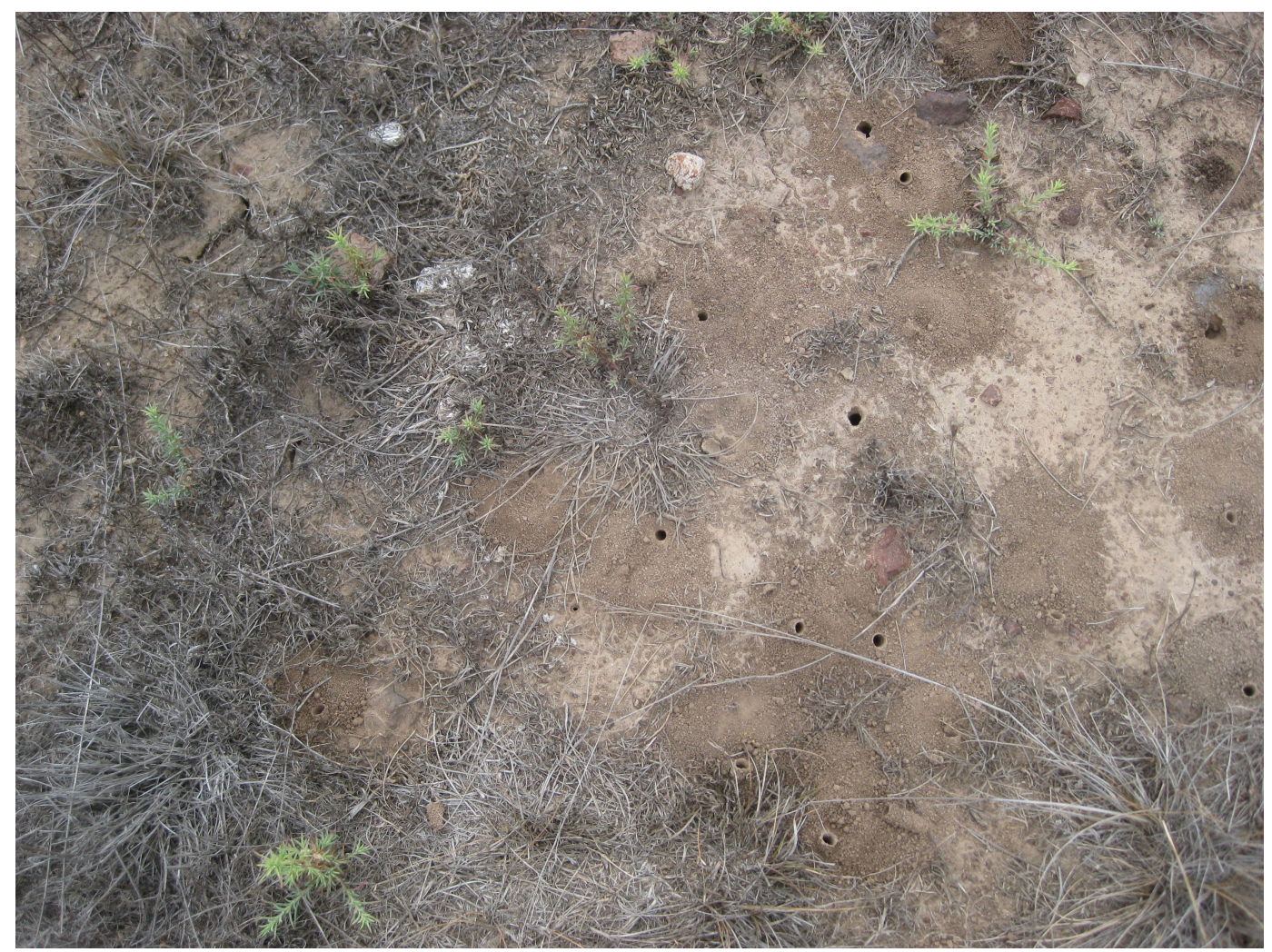

Fig. 1. Image of nest site aggregation within maritime desert scrub-prickly pear (MDS-PP) phase vegetation in thirst stony fine loam. Circular nest holes are visible, some with turrets and some without.

the habitat of the nesting sites (TDI 2013). Landform types included the following: hills and terraces, sand dunes, escarpments, high plateau clay grassland, and high plateau loamy grassland (Olmstead 1958, Muhs 1982). Soil types included the following: thirst stony fine loam, ustalf cobbly silt loam, Westshore silt loam, Shoba loam, eelpoint clay, and eelcove fine sandy loam (Muhs 1982). Vegetation types included the following: maritime desert scrub (MDS)-Lycium phase, MDS-prickly pear phase, MDS-cholla phase, maritime sage scrub, and none (bare ground) (USDoN SWDIV 2001).

\section{RESULTS}

Overall, 50 nest aggregations were located within the 5-month period in 2015 (Table 1). We observed 29 sites with bee activity, and of those, the authors collected and identified bees from 12 sites. The majority (9 bees) were identified as Diadasia bituberculata (Cressfon), and 2 were identified as D. opuntiae Cockerell. Collectively, Diadasia spp. include species commonly known as cactus bees. One bee was identified as Anthidium collectum Huard, which is known to use abandoned nests of other bees (Hicks 1929). We also collected and identified an ecotoparasitic fly, Bombylius major L. (Boesi et al. 2009), which we observed ovipositing into nesting holes at nest site 20 (Figs. 2, 3)

Although bees nested across the island, identified nests were found on some landforms, vegetation, and soil types more often than others. Just over half $(52 \%)$ of the nest sites were found on the high plateau loamy grassland landform type. Approximately a quarter $(24 \%)$ of nest sites were found on hills and terraces. One nest was found in sand dunes and the remaining were found on escarpments or high plateau clay grassland. In relation to vegetation cover, 27 nest sites (54\%) were found in MDS-prickly pear phase, $11(22 \%)$ in MDS-Lycium phase, 6 (12\%) in 


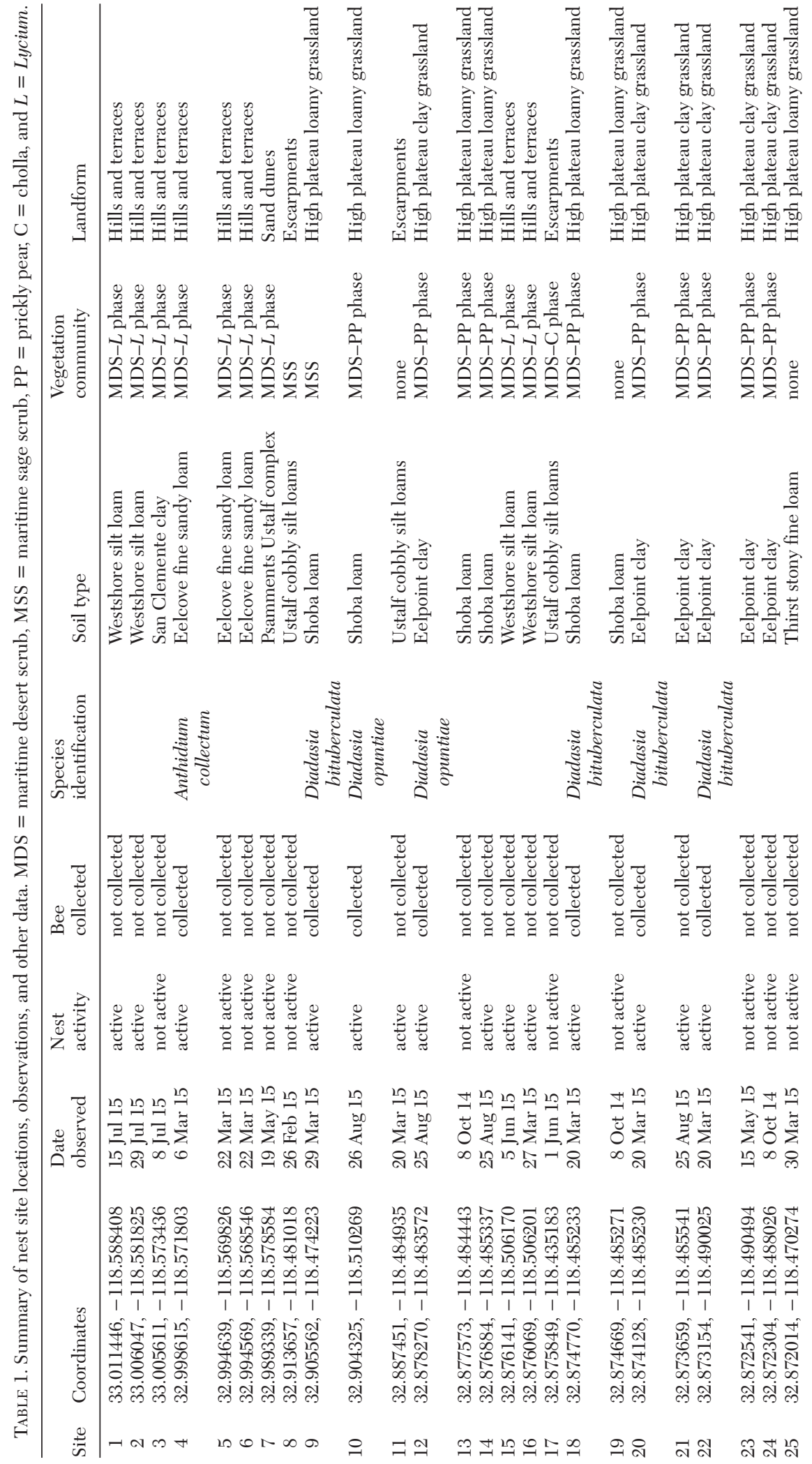




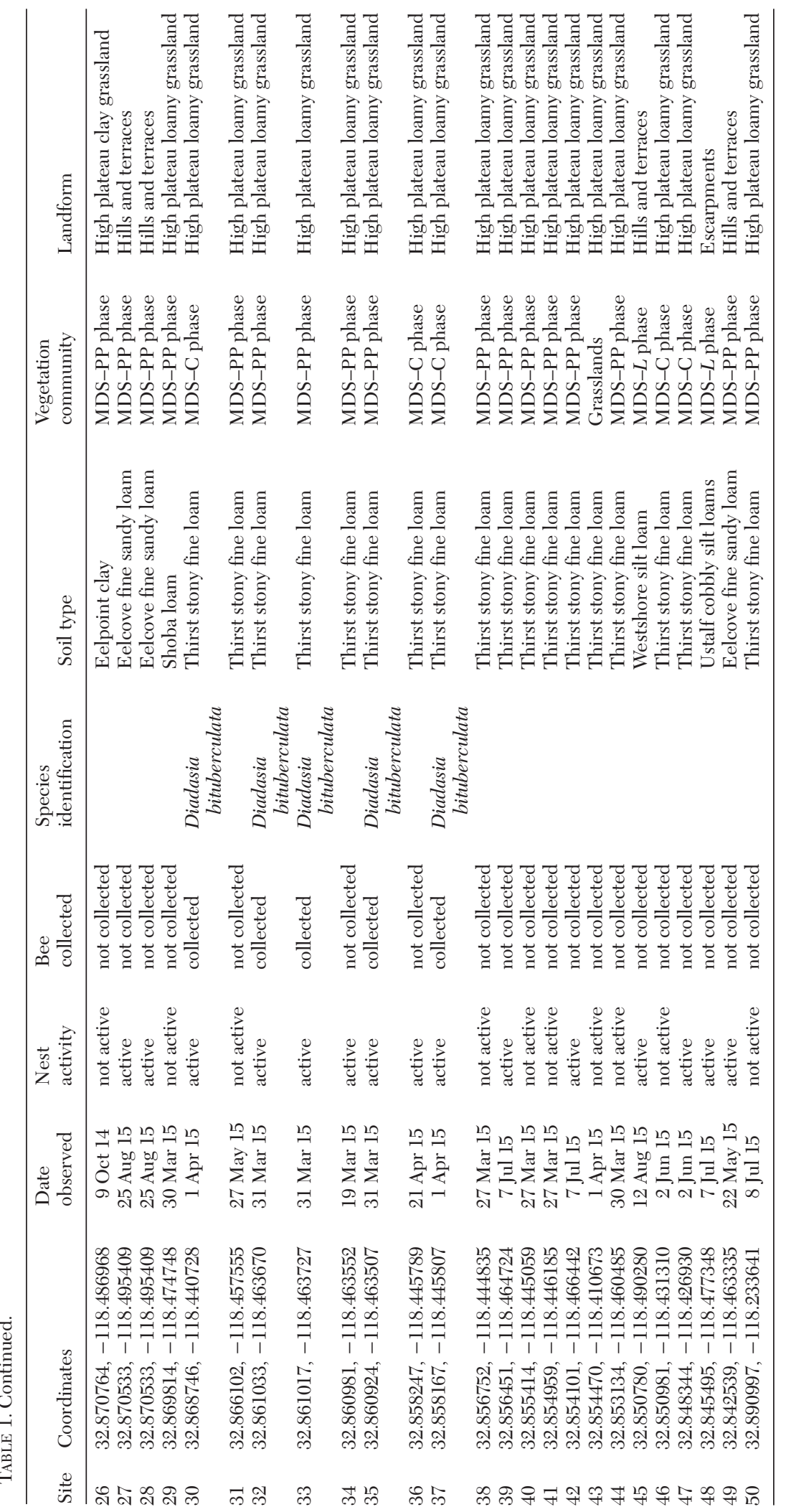




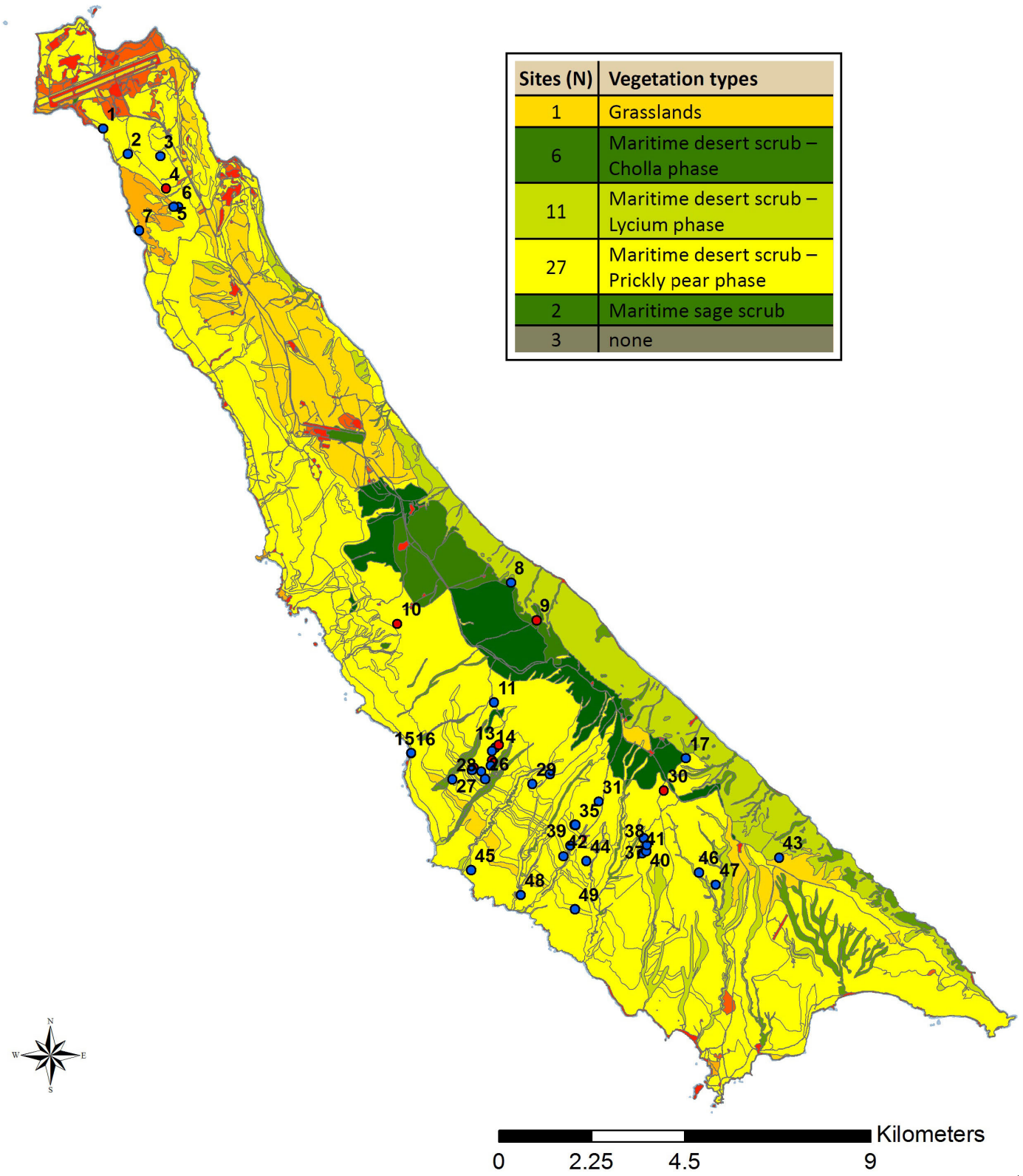

Fig. 2. Map of San Clemente Island vegetation cover. The inset table summarizes the number of sites (nest aggregations) found within each cover type. Site numbers are denoted north to south. Site marks in red indicate where bees were collected; site marks in blue indicate where sites were observed but bees were not collected.

MDS-cholla phase, 2 in maritime sage scrub, 1 in grassland, and 3 in areas lacking vegetation (Fig. 2). In relation to soil type, most nesting sites $(82 \%)$ were located in a loamtype soil; $38 \%$ of nest sites were found in thirst stony fine loam soil, while another $16 \%$ were found in clay type soil, and 1 was found in pasamments-ustalf complex soil (Fig. 3).
Of all the nest sites sampled, $42 \%$ were inactive at the time of observation, but gregarious nesting patterns and visible fresh turrets are highly suggestive of recent nesting (North and Lillywhite 1980, Ordway 1984). Some of the sites $(36 \%)$ were large aggregations $(>30$ nests per $\mathrm{m}^{2}$ ) found directly on the compacted soil of old ATV trails and dirt roads. 


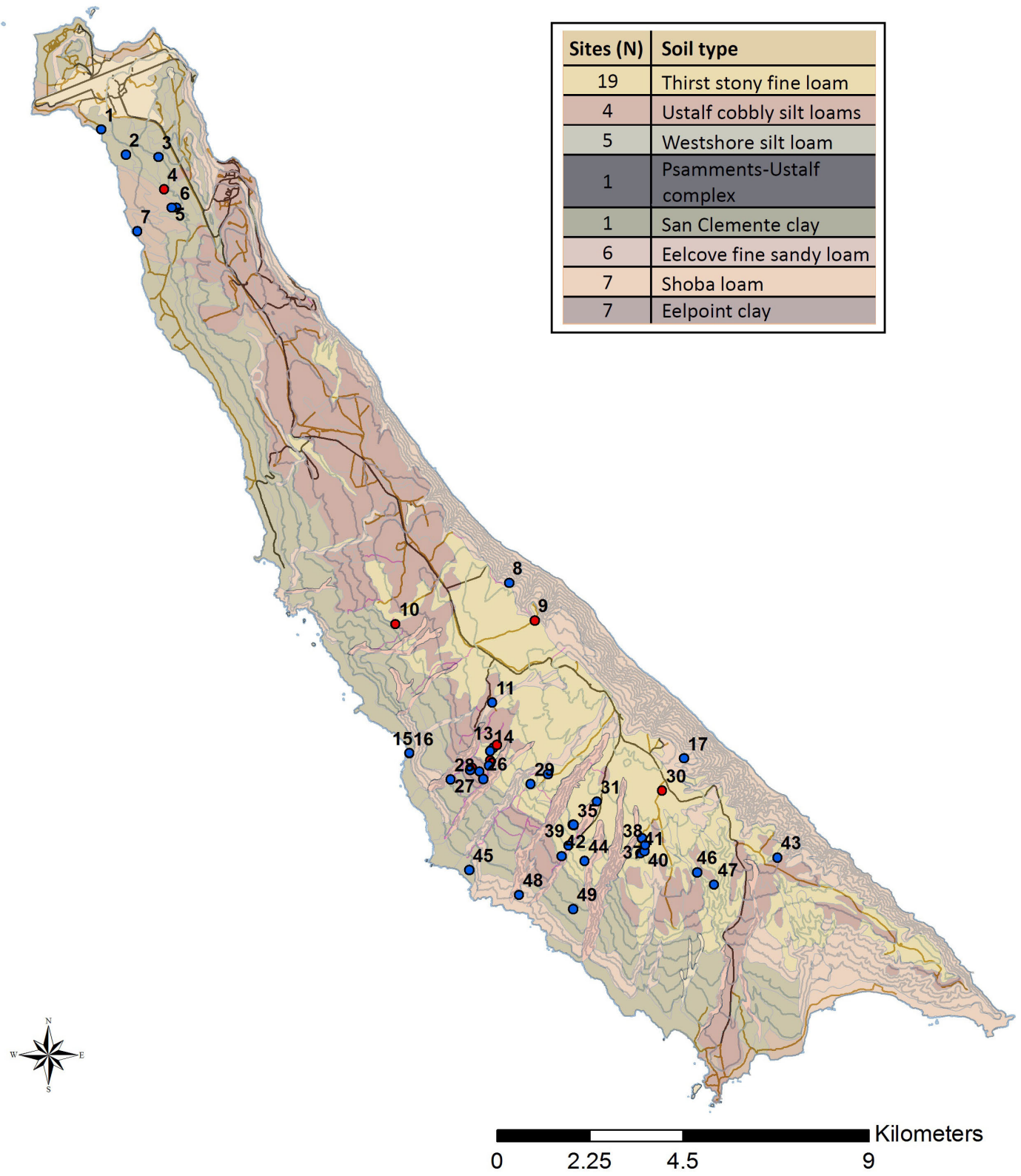

Fig. 3. Map of San Clemente Island soil types. The inset table summarizes the number of sites (nest aggregations) found within each soil type. Site numbers are denoted north to south. Site marks in red indicate where bees were collected; site marks in blue indicate where sites were observed but bees were not collected.

\section{Discussion}

To our knowledge, there are very few largescale solitary bee nesting surveys conducted in natural ecosystems. On San Clemente Island, we were able to find 50 nest sites in 5 months. Our success in locating many nest sites on the island may have resulted from the low-growing vegetation and numerous bareground patches throughout the landscape. Our collaboration with existing personnel and survey efforts involved multiple trained field biologists searching for nests while scouting the island for other species-monitoring projects. We acknowledge the limitations of these opportunistic sampling methods; nevertheless, 
our study provides the first mapping of native bee nesting habitat on the island, which may contribute to the growing study of solitary bee nesting habitat.

Nesting habitat patterns emerged, based on sampling effort. Thirst stony fine loam soils cover the highest elevation and upper marine terraces on the west side of the island where approximately half the nest sites were found. Most nesting sites were found within the dominant MDS-prickly pear phase vegetation cover. Almost all (92\%) of the Diadasia spp. collected were from nest sites located in cactusrelated vegetation (prickly pear and cholla), which is an expected association between cactus and cactus bees (Schlising 1972, Ordway 1984), and may suggest that inactive nest sites found in the same vegetation could also belong to Diadasia spp. Future and regular surveys of nesting habitat will improve maps and may have predictive potential.

It is interesting to note that $36 \%$ of located nest sites were found on human-disturbed, compacted soil. The association of nest sites with compact soil has been observed for several other bee species (Thorp 1969, Wuellner 1999, Sardiñas and Kremen 2014) and has been observed specifically for D. bituberculata in California and Arizona (Linsley and Macswain 1952, North and Lillywhite 1980) and for D. opuntiae in Arizona (Ordway 1984). Our observations suggest that some types of human-mediated changes in the environment may be beneficial for some bee species by creating preferred habitat (Heneberg et al. 2013). Because solitary ground-nesting bees create nests by tunneling into the soil (Michener 2007), compaction may contribute to nest integrity via improved structural support, which can allow for larger nest aggregations relative to those in undisturbed soil with less compaction, including ground immediately adjacent to trails (Potts and Willmer 1997).

There are recognizable challenges in protecting species in situ because of the level of management and monitoring required (Heywood and Iriondo 2003). Logistically, this in situ protection may be more difficult to accomplish in natural ecosystems compared to agricultural systems, which can be manipulated to a higher degree (Wade et al. 2008). Protecting bee nesting habitat in natural areas, however, could be incorporated within existing protection plans for the floral species they pollinate and protection plans for other organisms, such as birds, which may occupy the same habitat. Additional research may show that bees benefit as nontarget species of bird conservation because bees and birds use the same habitat patches (Heneberg 2012), or vice versa. If bees and birds share specific biological requirements such as nest substrate or food sources, areas with both of those resources could be prioritized. Determining habitat and resource needs of multiple species can help to identify overlapping resource requirements, streamline conservation strategies, and contribute to a comprehensive resource management plan that is cost-effective and efficient to implement (Barrows et al. 2005).

\section{ACKNOWLEDGMENTS}

We thank Sue Meiman, Emma DeLeon, Justyn Stahl, Stephanie Nefas, and Steve Munoz of the Institute for Wildlife Studies, as well as Stephanie Calloway, Korie Merrill, and Amanda Chisholm of the Soil Ecology and Restoration Group for their enthusiasm and assistance in locating bee nests. We also thank Dr. Doug Yanega of the UCR Entomology Research Museum for his help with bee species identification.

\section{Literature Cited}

Barrows, C.W., M.B. Swartz, W.L. Hodges, M.F. Allen, J.T. Rotenberry, B.-L. Li, T.A. Scott, and X. Chen. 2005. A framework for monitoring multiple-species conservation plans. Journal of Wildlife Management 69:1333-1345.

Boesi, R., C. Polidori, and F. Andrietti. 2009. Searching for the right target: oviposition and feeding behavior of Bombylius bee flies (Diptera: Bombyliidae). Zoological Studies 48:141-150.

BlaAuW, B., AND R. IsAaCS. 2014. Larger patches of diverse floral resources increase insect pollinator density, diversity, and their pollination of native wildflowers. Basic and Applied Ecology 15:701-711.

Cane, J.H. 1991. Soils of ground-nesting bees (Hymenoptera: Apiodea): texture, moisture, cell depth and climate. Journal of the Kansas Entomological Society 64:406-413.

Cane, J.H., T. Griswold, and F.D. Parker. 2007. Substrates and materials used for nesting by North American Osmia bees (Hymenoptera: Apiformes: Megachilidae). Annuals of the Entomological Society of America 100:350-358.

Dicks, L.V., A. Abrahams, J. Atkinson, J. Biesmeijer, N. Bourn, C. Brown, M.J.F. Brown, C. Carvell, C. Connolly, J.E. Cresswell, et AL. 2013. Identifying key knowledge needs for evidence-based 
conservation of wild insect pollinators: a collaborative cross-sectoral exercise. Insect Conservation and Diversity 6:435-446.

Haaland, C., R.E. Naisbit, and L.F. Bersier. 2011. Sown wildflower strips for insect conservation: a review. Insect Conservation and Diversity 4:60-80.

Heneberg, P. 2012. Flagship bird species habitat management supports the presence of ground-nesting aculeate hymenopterans. Journal of Insect Conservation 16:899-908.

Heneberg, P., P. Bogusch, and J. Rehounek. 2013. Sandpits provide critical refuge for bees and wasps (Hymenoptera: Apocrita). Journal of Insect Conservation 17:473-490.

Heywood, V.H., AND J.M. IRIondo. 2003. Plant conservation: old problems, new perspectives. Biological Conservation 113:321-335.

Hicks, C.H. 1929. Notes on habits of Anthidium collectum Huard. Canadian Entomologist 61:84-86.

Kearns, C.A., D.W. InOuye, and N.M. Waser. 1998. Endangered mutualisms: the conservation of plant-pollinator interactions. Annual Review of Ecology, Evolution, and Systematics 29:83-112.

Kier, G., H. Kreft, T.M. Lee, W. Jetz, P.L. Ibish, C. Nowicki, J. Mutke, and W. Barthlott. 2009. A global assessment of endemism and species richness across island and mainland regions. Proceedings of the National Academy of Sciences 106:9322-9327.

Linsley, E.G., AND J.W. MacsWain. 1952. Notes on some effects of parasitism upon a small population of Diadasia bituberculata (Cresson) (Hymenoptera: Anthophoridae). Pan-Pacific Entomologist 28:131-135.

M'Gonigle, L.K., N.M. Williams, E. Lonsdorf, and C. Kremen. 2016. A tool for selecting plants when restoring habitat for pollinators. Conservation Letters 10:105-111.

MichenER, C.D. 2007. The bees of the world. 2nd edition. John Hopkins University Press, Baltimore, MD.

Muns, D.R. 1982. A soil chronosequence on Quaternary marine terraces, San Clemente Island, California. Geoderma 28:257-283.

Myers, N., R.A. Mittermeier, C.G. Mittermeier, G.A.B. DA Fonseca, AND J. Kent. 2000. Biodiversity hotspots for conservation priorities. Nature 403:853-858.

North, F., AND H. Lillywhite. 1980. The function of burrow turrets in a gregariously nesting bee. Southwestern Naturalist 25:373-378.

O’Connor, S., K.J. Park, and D. Goulson. 2012. Humans versus dogs; a comparison of methods for the detection of bumble bee nests. Journal of Apicultural Research 51:204-211.

OlmSTEAD, F.H. 1958. Geologic reconnaissance of San Clemente Island California. Geological Survey Bulletin 1071-B, U.S. Geological Survey, prepared in cooperation with the U.S. Department of the Navy. U.S. Government Printing Office, Washington, DC.

ORDWAY, E. 1984. Aspects of the nesting behavior and nest structure of Diadasia opuntiae Ckll. (Hymen- optera: Anthophoridae). Journal of the Kansas Entomological Society 57:216-230.

Potts, S.G., B. Vulliamy, S. Roberts, C. O’Toole, D. Dafni, G. Ne'eman, ANd P. Willmer. 2005. Role of nesting resources in organizing diverse bee communities in Mediterranean landscapes. Ecological Entomology 30:78-85.

PotTs, S.G., AND P. Willmer. 1997. Abiotic and biotic factors influencing nest-site selection by Halictus rubicundus, a ground-nesting halictine bee. Ecological Entomology 22:319-328.

Rust, R., A. Menke, and D.R. Miller. 1985. A biogeographic comparison of the bees, sphecid wasps, and mealy bugs of the California Channel Islands (Hymenoptera, Homoptera). Pages 29-59 in A.S. Menke and D.R. Miller, editors, Entomology of the Channel Islands, proceedings of the first symposium. Santa Barbara Museum of Natural History, Santa Barbara, CA.

Sardiñas, H.S., and C. Kremen. 2014. Evaluating nesting microhabitat for ground-nesting bees using emergence traps. Basic and Applied Ecology 15: 161-168.

SCHLISING, R.A. 1972. Foraging and nest provisioning behavior of the oligolectic bee, Diadasia bituberculata (Hymenoptera: Anthophoridae). Pan-Pacific Entomologist 48:175-188.

Thorp, R.W. 1969. Ecology and behavior of Anthophora edwardsii (Hymenoptera: Anthophoridae). American Midland Naturalist 82:321-337.

[TDI] TIERRA DATA InC. 2013. Integrated natural resource management plan. Naval Auxiliary Landing Field, San Clemente Island, CA.

[USDoN SWDIV] United States Department of the Navy, Southwest Division. 2001. San Clemente Island Integrated Natural Resources Management Plan Draft Final. San Diego, CA.

Wade, M.R., G.M. GurR, and S.D. Wratten. 2008. Ecological restorations of farmland: progress and prospects. Philosophical Transactions of the Royal Society B Biological Science 363:831-847.

Williams, N.M., E.E. Crone, T.H. Roulston, R.L. Minckley, L. Packer, and S.G. Potts. 2010. Ecological and life-history traits predict bee species responses to environmental disturbances. Biological Conservation 143:2280-2291.

Wratten, S.D., M. Gillespie, A. Decourtye, E. Mader, and N. Desneux. 2012. Pollinator habitat enhancement: benefits to other ecosystem services. Agriculture, Ecosystems and Environment. 159:112-122.

Wuellner, C.T. 1999. Nest site preference and success in a gregarious, ground-nesting bee Dieunomia triagulifera. Ecological Entomology 24:471-479.

Received 28 February 2017 Revised 27 November 2017 Accepted 12 January 2018 Published online 29 October 2018 